IJAPS, Vol. 18, No. 1, 31-47, 2022

\title{
DOING GENDER AND RACE INTERSECTIONALITY: THE EXPERIENCES OF FEMALE MAORI AND NON- WHITE ACADEMICS IN NEW ZEALAND
}

\author{
Dzuriyatun Toyibah* \\ Department of Sociology, The Faculty of Social and Political Sciences, \\ Syarif Hidayatullah State Islamic University, Indonesia \\ E-mail: dzuriyatun.toyibah@uinjkt.ac.id \\ Irma Riyani** \\ Department of Qur'an and Tafsir Studies, The Faculty of Ushuluddin, Sunan \\ Gunung Djati State Islamic University, Bandung, Indonesia \\ E-mail: irmariyani@uinsgd.ac.id
}

Published online: 25 January 2022

To cite this article: Toyibah, D. and Riyani, I. 2022. Doing gender and race intersectionality: The experiences of female Maori and non-white academics in New Zealand. International Journal of Asia Pacific Studies 18 (1): 31-47. https://doi. org/10.21315/ijaps2022.18.1.2

To link to this article: https://doi.org/10.21315/ijaps2022.18.1.2

\begin{abstract}
Several studies that focus on Western settings like Canada, the United States, the United Kingdom, Australia, and New Zealand have found that gendered institutions within academic careers are still preserved through various means. These studies have verified that fewer women are in tenure track positions than men. Additionally, women have been receiving a lower salary and are seldom promoted. Several issues such as mobility, parenting, and gender bias in application and evaluation rate as well as gender citation gap are highly correlated with women's challenges in pursuing professorships. Nonetheless, there is still a lack of studies pertaining to the impact of the intersection of race and gender on the experiences of people of colour and minority groups in academia. The current study aims to explore the role that gender and race play among female academics, which includes the careers of Maori academics (the indigenous people of New Zealand) and non-white academics in New Zealand. Based on in-depth interviews conducted with 15 academic staff, including Maori and non-white academics in New Zealand, the current research corroborates the existing literature regarding the interplay of race and gender in

(C) Penerbit Universiti Sains Malaysia, 2022. This work is licensed under the terms of the Creative Commons Attribution (CC BY)(https://creativecommons.org/licenses/by/4.0/).
\end{abstract}


advancing academic career. Furthermore, this research also finds that the meritbased concept or objective indicators of academic excellence do not necessarily apply in New Zealand. On account of their gender and racial identities, women of minority groups and non-white academics frequently experience multidimensional marginalisation while pursuing their academic careers.

Keywords: Academic, gender, intersectionality, race, women of colour

\section{INTRODUCTION}

An academic career is naturally expected to be a professional and merit-based occupation. Meritocracy has always been accentuated in academic standards policies for research and teaching staff at all levels. However, many studies have shown that in many cases this standard policy is also influenced by many aspects outside the professional requirements such as race/ethnicity, gender, nationality, and sexuality (Skachkova, 2007; Bilimoria and Stewart, 2009). The current paper presents the experiences of academic staff in their promotion opportunities and career advancement by focusing on how female academics are "doing gender" in their family and personal life. Simply put, it is aimed at demonstrating how "doing gender" affects the career advancement of female academics. We will present the experiences that female academics have in their child-rearing and domestic roles in New Zealand. We compare the experiences of a group of female academics in their 40s and another in their 50s, which subsequently leads to an understanding of the effects imposed by neoliberal policies. Since early in their careers, the younger generation has, assumedly, been confronted by the implementation of several aspects of neoliberal policies, such as research audits. Comparatively speaking, the older generation began their career before the initiation of neoliberal regimes. Consequently, the challenges they have faced throughout their academic career may, arguably, have been dissimilar. Additionally, other aspects like race, country of origin, and faculty background are also investigated.

Although far less so for male academics, issues like child-rearing and commitment to family have been identified as impediments to academic career advancement for women (Baker 2012: 110). Undoubtedly, for male academics, having a family is more likely to improve their social capital, as family tends to put the male's (husband's) career as a greater priority to that of a female's (wife's) (Baker 2012: 111). Research by Monosson (2008) and Williams and Ceci (2012) state that a number of female academics wish for both a career and a family, yet the academic profession is constructed 
with male and masculine values, and female scholars are, thus, expected to behave as their male academic counterparts do. Baker (2012) notes that being childfree has, recently, become more commonplace among female academics in comparison to male scholars. Kemkes-Grottenthaler (2003) reports that many female academics postpone motherhood until they feel more assured of their career, but as a consequence, they find it too late to have children by then.

In addition, gender and racial discrimination continue to occur throughout all aspects of life, and educational institution is no exception. Moreover, scholars agree that gender and race mutually intersect and are bound in various interlocking and inseparable ways (Davis 2016). Discussions about doing gender and race intersectionality are also part of challenges faced by female academics in the era of neoliberalism (Acker 2017; Morley 2016; Toyibah 2020). Research on this particular topic has been thriving, particularly in the field of Science, Technology, Engineering, and Mathematics (STEM). Despite an increase in the number of minorities and women pursuing their careers and degrees in STEM fields, these disciplines continue to experience issues with gender equity: persistent and, in some cases, increasing levels of under-representation of women; unequal standards and opportunities for women in STEM; and the consistent gender gap in earnings (Tao 2018; Powers et al. 2016; Hill et al. 2010). Meanwhile, studies on non-STEM fields are rarely documented. The current study provides data from both STEM and non-STEM fields.

\section{INTERSECTIONALITY: INTERROGATING GENDER AND RACIAL DISCRIMINATION}

Black feminists have introduced the idea of intersectionality, and it is now used to describe gender and racial intersections found in social policy, STEM research careers, and academic careers (McIntosh 2005; Davis 2016; Hayes and Bigler 2015). Intersectionality is a theory well-suited to examine the multiple discriminations experienced by the study participants in this research. Although decades have elapsed since Kimberlé Crenshaw (1989) coined the term, women of colour still face discriminatory incidents concerning their race and gender such as being sexually harassed (Raj et al. 2020), being excluded from professional advancement opportunities, and being underestimated based on gender and cultural background (Colletti et al. 2000). The current article employs intersectionality in terms of identifying the problem related to 
women's experiences in their academic career and providing a fair opportunity for women, including women of colour, in advancing their academic careers in several universities in New Zealand. Numerous challenges have been confronted by these women, who for the most part are indigenous women of Maori and Asian descent, when working at these universities. The data in this article demonstrates the relevance of intersectionality as a point of analysis related to discrimination specifically in terms of gender and race in academic settings.

The present research is also guided by postcolonial feminist theory that places the experience of female academics of colour and indigenous origin in "the intersections of colonialism and neocolonialism with gender, nation, class, race, and sexualities in the different contexts of women's lives, their subjectivities, work, sexuality, and rights" (Rajan and Park 2000: 53). Accordingly, this theory argues that indigenous women and women of colour are viewed by the Western mindset as "the other" who are "incapable" of representing themselves. Changes in cultural, social, and political life in a global community should grant equal opportunity to everyone to express their maximum potential regardless of gender, religion, ethnicity, class, and others (Mohanty 1988; Parashar 2016).

Intersectionality, as initially presented, refers to black women's struggle to fight for a fair deal while experiencing discrimination on multiple fronts as a minority group (Crenshaw 1989). Their gender and racial existence are, to put it simply, neglected. Adhering to Dill and Zambrana (2009: 1) on intersectionality, the current article applies it as "a critical analytic lens to interrogate racial, ethnic, class, ability, age, sexuality, and gender disparities and to contest existing ways of looking at these structures of inequality". When first introduced, intersectionality merely dealt with questions of race, ethnicity, and gender discrimination. Contemporary intersectionality has expanded to encompass more classifications that include religion, disability, age, nationality, and sexuality (Dill and Kohlman 2012). Without any intent of simplifying the case at hand, this article uses intersectionality to deal with race and gender, since they are the two most common types of marginalisation experienced daily.

Intersectionality is, thus, used to interrogate how the system applied in educational institutions affects the specific identity of women, most of whom are women of colour. Bilge (2013: 405) suspects that the overtaking of this theory in a contemporary academic discourse should be "depoliticized". In most cases, the experiences do not correlate with their abilities and potential, but rather with their race or gender, or both. In this case, intersectionality 
functions as a critique of the system that is unsupportive of their endeavours. It is a critique of the structures that do not provide them with the necessary assistance. It is a critique of the circumstances that do not allow them to attain their maximum potential simply because they are women; because they are not white; because they are different from most of the rest. By employing the theory of intersectionality, we not only intend to question the unequal treatment given by the institution but to transform inequality into justice as well. In this case, the current article is aimed at examining the discrimination imposed upon others by institutions that subsequently affect individuals or groups in pursuing academic career advancement. This is a significant issue, since educational institutions serve as a place for disseminating knowledge to the general public (Harris and Patton 2019). Accordingly, the interrogation is correlated with the system, policies, procedures, and programmes that operate in educational institutions. Applying this theory is expected to "challenge all forms of discrimination" experienced by women, including women of colour and indigenous origin, so that the institution could provide an equal and fair opportunity for all. The intersectionality theory in our research is, essentially, employed as "a frame for racially minoritised groups" (Harris and Patton 2019: 360).

\section{RESEARCH METHOD}

In-depth interviews are used as the method for the current study, in which data are gathered to acquire information in an unstructured manner; accordingly, the prompts comprise a list of closed or open-ended questions. The interviews cover the following topics: family life, parenthood, and the intersectionality of gender and race. The current article is based upon in-depth interviews carried out with 10 participants from two prominent universities in Auckland, New Zealand (University One and University Two) in 2015, with various criteria concerning age, school/department, and countries of origin. A plurality of the participants in the study are from New Zealand (one Maori and two Pākeh $\bar{a})^{1}$, two from the United Kingdom (U.K.), two participants from Europe, and one each from Latin America, Australia, and the United States (U.S.). The participants are recruited through the first author's work connections. The questions for this study are inspired by reading the existing body of literature on the topics and seeking out some important aspects related to gender gaps in academic careers for further investigation. During the interview, other questions come up as a part of elaborating from the participants' answers. 
In the study, three out of ten of the female participants do not have children. A participant (approximately 50 years old) who is single explained that she began her university career at 27, kept focusing on her career, and did not start a family (a European female academic). Another female scholar (approximately 40 years old) from the U.S. is in a same-sex marriage and has decided to be childfree. She does not feel the need to have children; she deems child-rearing as complicated and child-care as being too costly. In the same tune, a married, child-free, heterosexual (approximately 50 years old) maintains a similar argument: she never had a desire to bear children. Nonetheless, she enjoys the company of other people's children without having to have them herself (a female scholar from the U.K.). Arguably, the current study indicates a similar trend to previous studies reported by Baker (2012) and Kemkes-Grottenthaler (2003), wherein being childless is not uncommon among female academics, and accordingly, the fertility rate is unsurprisingly low among women in this profession.

The remaining seven participants are married with children: four of the remaining participants are approximately 40 years old, while the other three are approximately 50 years old. Based on the interviews, the research results show similar trends to previous studies from Baker (2012), that female academics who chose to have a family and children are more likely to have enduredslowercareerdevelopment, particularlyifthey areyounger. Meanwhile, their partners conform to traditional male models. Female academics in their 40s who are mothers and have strong domestic responsibilities are less senior in rank than a mother who has fewer domestic obligations and a stay-athome husband. Three mothers in their 40s acknowledged that since they are responsible for $80 \%$ to $90 \%$ of domestic jobs in the household, their careers had been slower than their male colleagues. Meanwhile, a female scholar of similar age accompanied by a stay-at-home husband has seen a greater progression. Detail information of the participants are provided in Table 1.

Table 1: Research participants

\begin{tabular}{lcrll}
\hline $\begin{array}{l}\text { Control number of } \\
\text { participant }\end{array}$ & Age & Gender & Country of origin & School \\
\hline No. 1 & 50 & F & Europe & STEM \\
No. 2 & 41 & F & U.K. & STEM \\
No. 3 & 41 & F & Latin America & STEM \\
No. 4 & 55 & F & U.K. & STEM \\
No. 5 & 42 & F & New Zealand & STEM \\
No. 6 & 54 & F & New Zealand & Non-STEM \\
\hline & & & & (continued on next page)
\end{tabular}


Table 1: (continued)

\begin{tabular}{lcrll}
\hline $\begin{array}{l}\text { Control number of } \\
\text { participant }\end{array}$ & Age & Gender & Country of origin & School \\
\hline No. 7 & 42 & F & U.S. & Non-STEM \\
No. 8 & 54 & F & New Zealand & STEM \\
No. 9 & 50 & F & Europe & Non-STEM \\
No. 10 & 41 & F & Australia & Non-STEM \\
\hline
\end{tabular}

\section{FINDINGS AND DISCUSSION}

\section{Doing Gender, Family Life and Parenthood}

Doing gender is most apparent in family life and parenthood. Generally speaking, a family is a traditional institution established to maintain affective social action, it is not a rational instrument. The gendered division of labour in family life is still the mainstream value. The value of equality cannot be implemented in a traditional family. The decision to establish a family has serious consequences for the career paths of female academics. Hence, Baker (2012) argues, understandably, that family enhances social capital for male academics, whereas for women it is more constraining.

Most literature presents similar findings in terms of the effect that family and parenthood have on academic careers (Baker, 2009; Mason and Goulden, 2004). Mason and Goulden (2004) state that data in 2002 indicate that women who have babies late or have no children achieve higher tenure rates after five or more years post- $\mathrm{PhD}$ than women who have children early. Nonetheless, in 2004, they report that being married and having kids are not determining factors in the low level of women's tenure, since female academics who are not married and do not have children are still more likely to attain lower levels of tenure than men. Another key finding refers to the difference in family formation models between women and men in academia. Successful women academics, capable of moving up the academic ladder, tend to delay marriage and childbirth. Maureen Baker (2009) who examines perceptions of the impact of gender and family circumstances on academic careers supports their findings. She has found that male and female academicians have assorted experiences and priorities at work and home. She has identified that differences in human and social capital affect the gender gap in universities such as working conditions, job satisfaction, promotional opportunities, and expectation of productivity. 
Bailyn (2003) argues that an academic career does not only allow more flexibility, autonomy, and opportunity for people but, to some extent, it is also considered demanding, specifically for individuals engaged in other activities aside from academic work. For instance, women are assumed to confront more challenges than men do when dealing with an academic career as they, generally, carry out more domestic work. It is deemed demanding due to the numerous tasks that embody teaching, research, and service to the university. An academic career is similar to doing a field study, conducting an experiment, or writing a book, which cannot be immediately achieved. It is an enduring process conducted over quite a long period before seeing an apparent outcome.

Bailyn (2003) shows that an academic career is entrenched with work overload. Furthermore, she reveals that those working in academia will encounter numerous mental pressures. She asserts that academic faculty members, specifically those who have obtained professorships, should have a high level of competence in their field and are not expected to require help from others. Faculty members in the U.S. (and some countries with similar systems) must convince others of their ability in their field within the first seven years of their career. To some extent, an academic career is, thus, only appropriate for people who are able to provide most of their time and interest for academic work. Some prior studies conducted by Bagilhole (2003) and Forster (2001) have identified processes contributing to the marginalisation of women in universities in the U.K., which is apparent in both formal and informal recruitment and selection processes, probation, career development, promotion, and appraisal systems. The gender gap situation in those countries raises questions of how and why it constantly occurs, what different strategies are available to reduce it, and the output and outcome for institutional policy and family life.

Recent research by Beddoes and Pawley (2014) as well as Howe-Walsh and Turnbull (2014) have revealed similar findings. Despite the availability of numerous policies recommended by previous studies to improve the situation, Beddoes and Pawley (2014) argue there have only been minor changes. They contend that considering the gendered family roles as an individual choice has resulted in the current status quo. Additionally, Howe-Walsh and Turnbull (2014: 415) present similar findings that the gender segregation for female and male academics has significantly increased in science and technology disciplines. They specify that the factors leading to this gap have remained unchanged from previous studies, such as female academics facing a gendered environment from the start until the final stage in their career advancement 
path, and being left out of academic networks (Howe-Walsh and Turnbull 2014: 425). Female academics are still treated differently, as they are less recognised and lack clear guidance and strong support from their university. Most female academics in science and technology (ST) hold short-term contracts resulting in job insecurity. They face bullying and harassment and feel the discomfort of being perceived as "obtuse" and deemed ineligible in the field of ST, and these have had tremendous impact on their self-confidence. Very similar to prior research, Howe-Walsh and Turnbull have found that females in ST struggle to balance their family and career responsibilities.

Some exceptional findings regarding parenthood and academic career found in other literary sources indicate the invisibility of the gender gap and inconclusive results. Concerning this matter, Joecks et al. (2014) show that female researchers with children in business and economics have conducted more research than female researchers without children.

Regarding family commitment and parenthood, O'Connor et al. (2015) argue that male academics have different views on their commitment to careers and create a new move towards the relationship commitment. Although in many cases, they still adhere to preserve masculine privileges.

The participants in this study have maintained various positions concerning traditional family values that also influence their choices in committing to their university and family. According to an unmarried female senior lecturer from university one, there is no reason why females or males cannot have a career. Their family must support them, so they are able to properly pursue their career. Female academics cannot blame universities for not accepting women because of their domestic problems.

I mean they have to apply. And if they do not get support from their husband or their parents, I think it is an issue within the family.

A female academic living in a committed (but non-marital) partnership (originally from the U.S.) believes family life, parenthood, and taking responsibility outside the university disturb career advancement.

I think it is still really, really hard. I think that you must get a partner who is really helping you. You can do it, but it is exhausting. Like you want to have a baby in graduate school or have them once you get your 10 years, but most people don't combine being successful early on in their career and having children. 
Informants in their 50s who have children do not consider their family life and parenthood as an obstacle. They have achieved senior positions. First, a female professor from University Two in New Zealand. She started as tutor and climbed up to become lecturer; she was later promoted to senior lecturer, then associate professor, and was ultimately appointed as professor at another university in 2003. It is only because her husband is also an academician, thereby making them an academic couple who enjoys certain flexibility. Her husband entered academia before she did, and they acquired their professorships at the same time.

I said that is the advantage that we had, as a dual-career couple, academic career couple, as sabbaticals came so we could go away together. Other people, if their husband is not an academic and the sabbatical comes along and they cannot go overseas for a long period if they have a family. So we have some advantages, that's what I was trying to say.

Second, a female Maori Associate Professor is a feminist, yet she acknowledges that many of her practices are in line with traditional divisions of labour found in most families.

I do nearly all the cooking, and I consider myself a feminist, I grew up in a strong feminist background, and yet my home life...very much reflects the traditional division of labour. I find cooking very satisfying, very relaxing; I love the idea of cooking for my family.

Women scholars from the earlier generation are able to adjust to domestic tasks without difficulties, and they seldom see it as a hindrance to their careers. However, the younger generation has not enjoyed their family life the same way that the older generation has. The challenge that women working at university face, as described below, is balancing between family and career. Research by Stringer et al. (2018) shows that women are more likely to choose more flexible work than men do on account of their family commitment. Accordingly, due to their "double shift" workload (at home and the office; cf. Hochschild 1989), women have limited time to prepare for their research or pursue a higher academic position. Additionally, the patriarchal culture of glorifying housework as an ideal women's job remains embedded in society (Damaske and Gerson 2008).

This position was strengthened by the data from female academics from the U.K. and South America. The gendered division of labour in their families was initially forced upon them to enjoy their role as a parent, and 
they, eventually, came to accept it voluntarily. As a senior lecturer originally from the U.K. put it:

Because I have children, and so I have advanced more slowly. My career has been affected by spending time at home.

Raising children is an immense challenge for academics as it is timeconsuming, which consequently affects the time for research. One could say that academics who are childless or child-free will produce more research than those with such care responsibilities. On the other hand, having children may invoke academics with zeal and spirit to work harder in order to economically survive (Joecks et al. 2014). Having children has, generally, been considered as unfavourable to a female academic's career, especially for those in their 40s. However, female scholars who are mothers have also decided to have children on account of other benefits. One participant originally from the U.K. who is a senior lecturer remains satisfied with her decision, despite the fact that her career is not as good as her colleague who is now a full professor at nearly the same age.

I think I am growing into a better person because I am a mother. ...

So, I have a friend who got a $\mathrm{PhD}$ at the same time as me, and she is a full professor now. She is a long way ahead of me. But I have two beautiful children, and I choose to do it part-time, and they were my choices.

From the findings above, it can be said that female academics have different opinions regarding domestic work, whether it is a private or public matter. Those who believe it is a private matter suggest resolving it within their own family to have a more equal division of labour. We did not find any participants who blame the university for their domestic affairs. On the contrary, they understand their choice to take the risk of being a traditional mother. They have a choice to benefit from their university's support system, such as day care and other facilities, yet they are satisfied to raise their children themselves.

It is quite intriguing that while having a family is deemed to impede the career of female scholars, our study has found that unmarried and childfree women scholars are still more likely to attain a lower level of tenure than men. 


\section{Intersectionality of Gender and Race}

According to prior literature, the gender gap can be considered a common issue in both Western and non-Western nations. Women academicians are trailing behind their male counterparts as a result of several interconnecting factors. It has been stated that cultural and structural aspects can help understand gender differences in an academic career. Academic career development, normatively speaking, should follow merit-based standards with academic contribution as the main factor in career advancement, wherein research productivity is determined as one of the most authoritative measures of academic contribution.

Besides gender, race/ethnicity is a powerful issue, and both male and female participants have mentioned this. Nakhaie (2007) and Skachkova (2007) have found that white males and non-immigrants tend to be given a promotion to professor more easily than academics with an immigrant background or a person of colour. Female academics are assessed based on prejudicial academic standards in which teaching is less esteemed than research and publication. As a matter of fact, female academics tend to be more involved in teaching than research and publication. As a consequence, female academics consider the present promotion system as exhausting and as having a high administrative workload, which makes them reluctant to work through the system (Pyke 2013: 451). Many have, thus, decided to accept their current rank and are less interested in applying for promotion on account of the complicated situation they would face if they did.

Confirming past literature, some informants consider the criteria for promotion as being disadvantageous to non-white academics. A female associate professor from Australia put it this way:

I think from the time you are born if you are white, you have all sorts of little benefits that you do not even recognise. Speaking English, it is so easy for me to write an article in perfect English and get it accepted for publications, whereas if English is not your first language, it is much harder to get that perfect grammar, and so, it makes it so much harder to get published, and if you cannot get published, you can't get a promotion, and this is how it works.

This is echoed by another participant:

I suppose being an outspoken woman of colour seems to be a threat. I think it still happens everywhere, not unique in one university. It is easier for women of colour to stay quiet or who are obsequious, but I have no intention of being like that. 
The excerpts above indicate that privileging "white" remains the norm in several universities in New Zealand. Female academics of colour have experienced disadvantages for their race and gender. Their ability is considered only third, after their gender and race. The discrimination they have experienced in most cases is, thus, associated with gender and race. In this case, race and gender interfere with the decision-making process apart from the issue being discussed (Crenshaw 1989).

The citation below provides an explanation that the institution's discrimination against its staff affects individuals (or groups) in their career advancement. In this case, the distribution of work given by the university, unequally, prevents them from preparing for a higher rank. Harris and Patton (2019: 354) suggest that this situation should not be happening in educational institutions as it is a place to "produce transformative knowledge, informs praxis, and work towards social justice". The institution undermined the staff's potential simply because they are non-white. According to a participant who is an associate professor:

I suppose there is a hierarchy...there are times for somebody younger...there are times for somebody older. In terms of gender, it cannot be separated from your ethnic background. The hierarchy remains everywhere else, white male and white female; black male and black female, it has not changed in any way. I do not think that will change for a long time, the university here is headed by a white male or a white female.

On the other hand, a child-free female academic from the U.K. describes how her career advancement ran smoothly:

I was told that the post was vacant... I was not thinking of an academic post in that stage....and I was quite happy working for myself...so I just put an application to test the water with my CV, because I thought, it is not an academic CV, I do not have an academic career profile... some people will disclaim it immediately...but in this case...for some reason...they did not...probably it was the practical experience because we have a professional programme here. So, I am teaching professionals to become planners. It is good to help people with practical experiences as well.

Based on the experiences stated, intersectionality is a lens to interrogate how systems influence specific identities. In the context of academic careers, the most crucial identities are gender and race. Women of colour, in this case, 
have experienced much broader discrimination than white women and men of colour. Hierarchical structures of universities in New Zealand that put women of colour and indigenous origin at a lower level still occur. Intersectionality in this case is used to identify the problem and projected to transform unequal structures within the university and give equal opportunity to all. It challenges all forms of discrimination.

\section{CONCLUSION}

The current article presents data related to doing gender and family life and multiple discriminations experienced by female academics of colour and indigenous origin in "white" dominated universities. Hierarchical structures that give privilege to white and male academics and staff have placed those women in a complex situation. Academics who are mothers, academics of colour, and local indigenous New Zealand scholars are more likely to state that the system has them at a disadvantage. They tend to hold a strong family commitment or a solid social commitment to the community, which is something that is undervalued in relation to their career progression. They strain to compete in an "unfriendly" environment to find their space and path to advance their career. Such a situation ensued as a result of their not being considered adequately able to do their job, not because of the potential they possess but simply because they are women and not white. Through intersectionality analysis, this article demonstrates the challenges they confront in the academic environment to go against these oppressions and discriminations either individually or in a group and transform it into equal power relations.

\section{COMPLIANCE WITH ETHICAL STANDARDS}

Survey participation was gained through informed consent of respondents in accordance with procedures standard in The University of Auckland, New Zealand social science research.

\section{ACKNOWLEDGEMENTS}

We would like to thank Tracey McIntosh (The University of Auckland), Bruce Curtis (University of Waikato), Kevin W. Fogg (Carolina Asia Center, 
UNC-Chapel Hill), and Ai Fatimah Nur Fuad (Universitas Muhammadiyah Prof. DR. HAMKA [UHAMKA], Jakarta) for their feedbacks. This study is funded by the New Zealand ASEAN Scholarship (NZAS).

\section{NOTES}

* Dzuriyatun Toyibah is an academic staff in the Sociology Department of the Syarif Hidayatullah State Islamic University in Jakarta. She is also currently Vice-dean of Finance and Administrative Affairs for the Faculty of Social and Political Sciences at the same university. Her research interests include gender, neoliberalism in higher education, gender and political participation, Islamism, Indonesian Muslim diaspora and Indonesian Islamic organisation.

** Irma Riyani is a lecturer in the Qur'an and Tafsir Department of the Sunan Gunung Djati State Islamic University in Bandung, West Java. Her research interests include women and gender in Islam, sexuality in Indonesian Islam, feminist hermeneutical approaches to the Qur'an and Islamic studies.

1 Pākehā is a Māori language terminology for New Zealanders who are of European origin.

\section{REFERENCES}

Acker, S. 2017. Feminist scholars working around the neoliberal university. Gender and Education 31 (1): 62-81. https://doi.org/https://doi.org/10.1080/09540253.2017.1 296117

Bagilhole, B. 2003. Prospects for change? Structural, cultural and action dimensions of the careers of pioneer women Priests in the Church of England. Gender, Work and Organization 10 (3): 361-377. https://doi.org/10.1111/1468-0432.00200

Bailyn, L. 2003. Academic careers and gender equity: Lessons learned from MIT. Gender, Work and Organization 10 (2): 137-153. https://doi.org/10.1111/1468-0432.00008

Baker, M. 2012. Academic careers and the gender gap. Vancouver: UBC Press. . 2009. Gender, academia and the managerial university. New Zealand Sociology 24 (1): 24-48.

Beddoes, K. and Pawley, A. L. 2014. "Different people have different priorities": Workfamily balance, gender, and the discourse of choice. Studies in Higher Education 39 (9): 1573-1585. https://doi.org/10.1080/03075079.2013.801432

Bilge, S. 2013. Saving intersectionality from feminist. Du Bois Review: Social Science Research on Race 10 (2): 405-424. https://doi.org/10.1017/S1742058X13000283

Bilimoria, D. and Stewart, A. J. 2009. "Don't ask, don't tell": The academic climate for lesbian, gay, bisexual, and transgender faculty in science and engineering. NWSA Journal 21 (2): 85-103. https://doi.org/10.1353/nwsa.0.0077

Colletti, L. M., Mulholland, M. W. and Sonnad, S. S. 2000. Perceived obstacles to career success for women in academic surgery. Archives of Surgery 135 (8): 972-977. https://doi.org/10.1001/archsurg.135.8.972 
Crenshaw, K. 1989. Demarginalizing the intersection of race and sex: A black feminist critique of antidiscrimination doctrine, feminist theory and antiracist politics. University of Chicago Legal Forum 1989 (1): 139-167.

Damaske, S. and Gerson, K. 2008. Viewing 21st century motherhood through a workfamily lens. In Handbook of work-family integration, eds. Korabik, K., Lero, D. S. and Whitehead, D. L., 233-248. Cambridge, MA: Academic Press. https://doi. org/10.1016/B978-012372574-5.50016-8

Davis, D. R. 2016. The journey to the top: Stories on the intersection of race and gender for African American women in academia and business. Journal of Research Initiatives $2(1): 1-12$.

Dill, B. T. and Kohlman, M. H. 2012. Intersectionality: A transformative paradigm in feminist theory and social justice. In Handbook of feminist research: Theory and praxis, ed. Hesse-Biber, S. N. (2nd ed.). Thousand Oaks, CA: Sage Publications. https://doi.org/10.4135/9781483384740.n8

Dill, B. T. and Zambrana, R. E. 2009. Critical thinking about inequality: An emerging lens. In Emerging intersections: Race, class, and gender in theory, policy, and practice, eds. Dill, B. T. and Zambrana, R. E., 1-20. New Brunswick, NJ: Rutgers University Press.

Forster, N. 2001. A case study of women academics' views on equal opportunities, career prospects and work-family conflicts in a UK university. Career Development International 6 (1): 28-38. https://doi.org/10.1108/13620430110381016

Harris, J. C. and Patton, L. D. 2019. Un/doing intersectionality through higher education research. The Journal of Higher Education 90 (3): 347-372. https://doi.org/10.1080 /00221546.2018.1536936

Hayes, A. R. and Bigler, R. S. 2015. Postbaccalaureate STEM students' perceptions of their training: Exploring the intersection of gender and nativity. International Journal of Gender, Science, and Technology 7: 180-204. https://doi.org/http://hdl.handle. net $/ 10950 / 2580$

Hill, C., Corbett, C. and St. Rose, A. 2010. Why so few? Women in science, technology, engineering, and mathematics. Washington, DC: AAUW.

Hochschild, A. R. 1989. The second shift: Working parents and the revolution at home. New York: Viking Penguin.

Howe-Walsh, L and Turnbull, S. 2014. Barriers to women leaders in academia: Tales from science and technology. Studies in Higher Education 41 (3): 415-428. https://doi.or $\mathrm{g} / 10.1080 / 03075079.2014 .929102$

Joecks, J., Pull, K. and Backes-Gellner, U. 2014. Childbearing and (female) research productivity: A personnel economics perspective on the leaky pipeline. Journal of Business Economics 84: 517-530. https://doi.org/10.1007/s11573-013-0676-2

Kemkes-Grottenthaler, A. 2003. Postponing or rejecting parenthood? Results of a survey among female academic professionals. Journal of Biosocial Science 35 (2): 213226. https://doi.org/10.1017/S002193200300213X

Mason, M. A. and Goulden, M. 2004. Marriage and baby blues: Redefining gender equity in the academy. The Annals of the American Academy of Political and Social Science 596: 86-103. https://doi.org/10.1177/0002716204268744 
McIntosh, T. 2005. Intersections of race, gender and social policy in Aotearoa/New Zealand: Waihi I te toipoto, kaua I te toiroa. In Racism and public policy, eds. Bangura, Y. and Stavenhagen, R., 271-294. London: Palgrave Macmillan. https:// doi.org/10.1057/9780230554986_11

Mohanty, C. 1988. Under Western eyes: Feminist scholarship and colonial discourses. Feminist Review 30 (1): 61-88. https://doi.org/10.1057/fr.1988.42

Monosson, E., ed. 2008. Motherhood, the elephant in the laboratory: Women scientists speak out (1st ed.). Ithaca, NY: Cornell University Press.

Morley, L. 2016. Troubling intra-actions: Gender, neo-liberalism and research in the global academy. Journal of Education Policy 31 (1): 28-45. https://doi.org/10.1080/02680 939.2015.1062919

Nakhaei, M. R. 2007. Universalism, ascription and academic rank: Canadian professors, 1987-2000. CRSAIRCSA 44 (3): 361-386. https://doi.org/https://doi.org/10.1111/ j.1755-618X.2007.tb01190.x

O’Connor, P., O'Hagan, C. and Brannen, J. 2015. Exploration of masculinities in academic organisations: A tentative typology using career and relationship commitment. Current Sociology 63 (4): 528-546. https://doi.org/10.1177/0011392115574859

Parashar, S. 2016. Feminism and postcolonialism: (En)gendering encounters. Postcolonial Studies 19 (4): 371-377. https://doi.org/10.1080/13688790.2016.1317388

Powers, B. W., White, A. A., Oriol, N. E. and Jain, S. H. 2016. Race-conscious professionalism and African American representation in academic medicine. Academic Medicine 91 (7): 913-915. https://doi.org/10.1097/ACM.0000000000001074

Pyke, J. 2013. Women, choice and promotion or why women are still a minority in the professoriate. Journal of Higher Education Policy and Management 35 (4): 444 454. https://doi.org/10.1080/1360080X.2013.812179

Raj, A., Freund, K. M., McDonald, J. M. and Carr, P. L. (2020). Effects of sexual harassment on advancement of women in academic medicine: A multi-institutional longitudinal study. E-Clinical Medicine 20: 100298. https://doi.org/10.1016/j. eclinm.2020.100298

Rajan, R. S. and Park, Y.-M. 2000. Postcolonial feminism/ postcolonialism and feminism. In A companion to colonial studies, eds. Schwarz, H. and Ray, S. Hoboken, NJ: Blackwell. https://doi.org/10.1002/9780470997024.ch3

Skachkova, P. 2007. Academic careers of immigrant women professors in the U.S. Higher Education 53: 697-738. https://doi.org/10.1007/s10734-005-1976-4

Stringer, R., Smith, D., Spronken-Smith, R. and Wilson, C. A. (2018). "My entire career has been fixed term": Gender and precarious academic employment in a New Zealand university. New Zealand Sociology 33 (2): 169-201.

Tao, Y. 2018. Earnings of academic scientists and engineers: Intersectionality of gender and race/ethnicity effects. American Behavioral Scientist 62 (5): 625-644. https://doi. org/10.1177/0002764218768870

Toyibah, D. 2020. Perempuan cendekia dan tantangan neoliberalisme. Yogyakarta: LKiS.

Williams, W. M. and Ceci, S. J. 2012. When scientists choose motherhood: A single factor goes a long way in explaining the dearth of women in math-intensive fields. How can we address it? American Scientist 100 (2): 138-145. https://doi. org/10.1511/2012.95.138 